\title{
Infantile cortical hyperostosis
}

\author{
L. FRÁŇA and M. SEKANINA \\ From the Department of Paediatrics, Hospital Nové Město Na Moravě, Czechoslovakia
}

Frán̆a, L., and Sekanina, M. (1976). Archives of Disease in Childhood, 51, 589. Infantile cortical hyperostosis. The genetic aspects of infantile cortical hyperostosis are discussed. A pedigree is presented, based on the history and clinical and radiological investigations of all living members of the family, with data from 11 cases with the condition in two generations, and one possible case from a third generation. The data suggest that an autosomal dominant gene with varying expressivity could be responsible in this family and, though the genetic outlook is unfavourable, it is fully balanced by the benign character of the disease.

A chronic form of infantile cortical hyperostosis affecting 2 girls and 1 boy in the family is described with a follow-up of 3 to 5 years. There was no deterioration in the general state of health of the patients and no abnormality was detected in laboratory investigations. At the end of the second year of life, curving of the long bones was usually present radiologically and the appositionless corticalis was paper thin with extended marrow cavity. With increasing age the bowing of the bones became less noticeable (but can be permanent in some cases), the corticalis thickened, while marrow cavity volume decreased. In the marrow cavities the remains of insufficiently resorbed original hyperostoses were seen. All the affected bones exhibited both numerous Park's stress lines and osteoporosis, more marked in the bones of the lower extremities. Even these changes disappeared with increasing age. Neither the metaphyses nor epiphyseal ossification centres were affected by the condition.

Infantile cortical hyperostosis was recognized as an entity and the name suggested by Caffey and Silverman (1945) on the basis of clinical and radiological findings in their 4 patients. Cases with similar symptoms, known as nonsyphilitic hyperplastic periostitis, had been reported previously (West, 1888; Roske, 1930; Meier, 1936; Chiari, 1938; Caffey, 1939; Ellis, 1939; Klotz, 1939; de Toni, 1943).

The cause and pathogenesis of infantile cortical hyperostosis is still unclear; a viral, bacterial, and toxic aetiology all seem improbable. Barba and Freriks (1953) suggested that embroyological dysosteogenesis may have been caused by an insufficient blood supply occurring during the third month of intrauterine development when rotation is known to take place. This does not explain the involvement of other than long bones, nor the fact that damage occurring so early does not manifest until well after birth, apart from a few reported exceptions (Jenkinson et al., 1943; Barba and Freriks, 1953; Bennett and Nelson, 1953). An

Received 24 November 1975. early extra-articular allergic reaction has been suggested (Caffey and Silverman, 1945; Caffey, 1946; Smyth, Potter, and Silverman, 1946; Mossberger, 1950; Eversole, Holman, and Robinson 1957; Sauterel and Rabinowicz, 1961).

We feel, together with others (Gerrard et al., 1961; Van Buskirk, Tampas, and Peterson, 1961), that a genetic aetiology could be involved with a different mechanism of heredity in different families (i.e. autosomal dominant in some and autosomal recessive in others).

Histologically, the early phase of infantile cortical hyperostosis is located intraperiosteally inside a richly cellularized and mitotically active periosteum. The surface fibrous membrane disappears and the reaction is extended to contiguous soft tissues and to the layer of subperiosteal osteoid trabeculae. During the subacute stage of the disease the periosteum is re-established as a complete unit, so that a bone newly built from ectopic osteoid trabeculae now appears subperiosteally. During the late phase of the disease, hyperostoses are removed by a process of resorption from inside.

The main symptoms of the early stage of infantile 
cortical hyperostosis can be characterized briefly as follows. (1) First symptoms appear within the first half year of life, and a diagnosis can also be made in utero (Jenkinson et al., 1943; Barba and Freriks, 1953; Bennett and Nelson, 1953). (2) Swelling of soft-tissue above the affected bones dominates the clinical picture. Swelling appears suddenly and is painful at the onset of the disease. It is of solid consistency, not sharply limited, fixed to the bone, and never fluctuates. No symptoms of skin inflammation or reaction in lymph nodes are observed. (3) The most typical and diagnostically most illustrative findings are obtained by $x$-ray examination. In the early phase of the disease bizarre forms of hyperostoses, in various stages of development, may be found above the compacta of various parts of the skeletons (see Fig. 2), often simultaneously in several places, including places where no swelling is detected by physical examination. Bone appositions are most frequently localized on the mandible, clavicles, ribs, scapulae, and the diaphyses of the long bones. (4) Some patients are irritable, with restricted mobility and raised temperature; laboratory investigations show leucocytosis, raised erythrocyte sedimentation rate, and alkaline phosphatase levels.

Swelling disappears completely within a few weeks in some patients, while in others it reappears later at the same site or elsewhere, and in some it persists for several months. Radiological findings persist in most cases for several months. Complete recovery by the end of the second year of life is reported by most authors and, though no specific therapy is available, the outlook is favourable.

A family with infantile cortical hyperostosis is reported and the chronic course of the disease in 3 of its members is described. Published reports of cases with an atypical course are discussed.

\section{Case reports}

Family. The pedigree of the family is shown in Fig. 1. A history was taken and physical and radiological examination made of all bones most frequently affected in all living members of the family (Table). There was no known consanguinity and the affected members of generation IV were all investigated during the acute phase of the disease.

The history showed that patient III.1 had had painful episodes of swelling of the legs at 2 months of age with spontaneous improvement about 7 months later; patient III.2 had had swelling of the lower jaw at 3 months and swelling, followed by bowing, of the right leg. All symptoms improved spontaneously during the first year of life. Patient II.1 had had crura vara from early childhood, a finding which the authors confirmed.

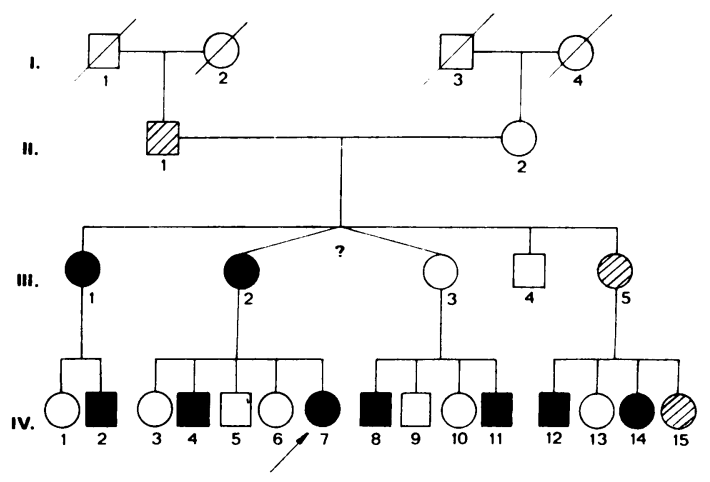

FIG. 1.-Pedigree of family with infantile cortical hyperostosis.

$\square, \square$ males; $\bigcirc$, females;, $\mathbf{\square}$, individuals with clinical manifestations of infantile cortical hyperostosis; $\%, \nVdash$, individuals with radiological findings only.

\section{TABLE}

Correlation between clinical and radiological manifestations of infantile cortical hyperostosis

\begin{tabular}{|c|c|c|c|c|}
\hline $\begin{array}{l}\text { Family } \\
\text { member }\end{array}$ & $\begin{array}{c}\text { Year } \\
\text { of } \\
\text { birth }\end{array}$ & $\begin{array}{l}\text { Clinical } \\
\text { manifestation } \\
\text { of disease }\end{array}$ & $\begin{array}{c}X \text {-ray } \\
\text { findings } \\
\text { during acute } \\
\text { state of } \\
\text { disease }\end{array}$ & $\begin{array}{c}X \text {-ray } \\
\text { findings } \\
\text { obtained } \\
\text { in } 1971\end{array}$ \\
\hline $\begin{array}{l}I .1 \\
I .2 \\
I .3 \\
I .4\end{array}$ & $\begin{array}{l}1883 \\
1885 \\
1887 \\
1889\end{array}$ & $\begin{array}{l}0 \\
0 \\
0 \\
0\end{array}$ & $\begin{array}{l}\mathbf{N} \\
\mathbf{N} \\
\mathbf{N} \\
\mathbf{N}\end{array}$ & $\begin{array}{l}\mathbf{N} \\
\mathbf{N} \\
\mathbf{N} \\
\mathbf{N}\end{array}$ \\
\hline $\begin{array}{l}\text { II.1 } \\
\text { II. } 2\end{array}$ & $\begin{array}{l}1907 \\
1914\end{array}$ & $\begin{array}{l}0 \\
0\end{array}$ & $\begin{array}{l}\mathbf{N} \\
\mathbf{N}\end{array}$ & $\begin{array}{l}+? \\
0\end{array}$ \\
\hline $\begin{array}{l}\text { III.1 } \\
\text { III.2 } \\
\text { III.3 } \\
\text { III.4 } \\
\text { III.5 }\end{array}$ & $\begin{array}{l}1934 \\
1935 \\
1935 \\
1940 \\
1945\end{array}$ & $\begin{array}{l}+ \\
+ \\
0 \\
0 \\
0\end{array}$ & $\begin{array}{l}\mathbf{N} \\
\mathbf{N} \\
\mathbf{N} \\
\mathbf{N} \\
\mathbf{N}\end{array}$ & $\begin{array}{l}+ \\
+ \\
0 \\
0 \\
+\end{array}$ \\
\hline $\begin{array}{l}\text { IV.1 } \\
\text { IV.2 } \\
\text { IV.3 } \\
\text { IV.4 } \\
\text { IV.5 } \\
\text { IV.6 } \\
\text { IV.7 } \\
\text { IV.8 } \\
\text { IV.9 } \\
\text { IV.10 } \\
\text { IV.11 } \\
\text { IV.12 } \\
\text { IV.13 } \\
\text { IV.14 } \\
\text { IV.15 }\end{array}$ & $\begin{array}{l}1954 \\
1956 \\
1956 \\
1958 \\
1961 \\
1967 \\
1970 \\
1956 \\
1958 \\
1964 \\
1969 \\
1965 \\
1967 \\
1968 \\
1973\end{array}$ & $\begin{array}{l}0 \\
+ \\
0 \\
+ \\
0 \\
0 \\
+ \\
+ \\
0 \\
0 \\
+ \\
+ \\
0 \\
+ \\
0\end{array}$ & $\begin{array}{l}0 \\
+ \\
0 \\
+ \\
0 \\
0 \\
+ \\
+ \\
0 \\
0 \\
+ \\
+ \\
0 \\
+ \\
+\end{array}$ & $\begin{array}{l}0 \\
+ \\
0 \\
0 \\
0 \\
0 \\
+ \\
0 \\
0 \\
0 \\
+ \\
0 \\
0 \\
+ \\
\mathbf{N}\end{array}$ \\
\hline
\end{tabular}

$\mathrm{N}, X$-rays not performed; 0 , negative observation; +, positive observation.

Radiologically, interest was focused not only upon the acute phase of the disease but upon the study of residual findings. Infantile cortical hyperostosis was 
confirmed radiographically in all patients of generation IV in whom it had been suspected from the history and clinical findings. Additional radiological damage was also observed in patients in whom it had not been detected by physical examination. For example, in patient IV.15 radiological signs only were observed, with no clinical findings. In generation III mild radiological curving of the left humerus and right tibia were observed in III.2, and mild curving of both femurs and the left humerus in III.5. No signs of the disease were observed in III.3 (nor in the history) though she must clearly have transmitted it to her offspring. She may have had such a mild case in infancy that it went unnoticed and left no residual radiological findings. Patient II.1 had radiological curving of the right humerus, an abnormally shaped right clavicle, and clinical and radiological crura vara.

All patients in the family had a negative history of injury. The Wassermann test in all patients was repeatedly negative and there were no syphilitic symptoms or stigmas in any patient.

An unusually prolonged course of the disease was observed in 3 patients in generation IV, patient IV.7, the propositus, and patients IV.11 and IV.14. The early stage of the disease was the same as that described in published reports and in the introduction to this report. Physical and radiological investigations were performed regularly in each patient, as well as erythrocyte sedimentation rate, blood count with differential count, calcium, phosphorus, alkaline phosphatase levels, and Mantoux test.

IV. 7 (propositus). Born on 1 January 1970. The disease appeared on the 7th day after birth manifesting as painful swelling of the left leg and restlessness. In the early stages the lower jaw, right clavicle, right humerus, left tibia and fibula were affected (Fig. 2). At 12 months of age all physical symptoms had disappeared with the exception of mild oedema and tenderness of the left tibia.

Radiology (Fig. 3) showed large hyperostoses of the left tibial diaphysis. The original corticalis is well defined only in the upper section of the bone, elsewhere it is hardly distinguishable from the marrow or the appositions. The long axis is not impaired, the marrow is not enlarged, and the density of the spongiosis is normal with fine trabeculae. At 2 years the oedema and tenderness had disappeared. Radiologically (Fig. 4), bowing of the tibia was obvious, the appositionless corticalis was thin, the marrow enlarged, and mild osteoporosis was present. Prednisone $1.5 \mathrm{mg} / \mathrm{kg}$ per day was given to the patient for 3 weeks at this stage.

At 3 years bowing of the tibia was still obvious (Fig. 5), the corticalis was thickened, the marrow was narrower, with remains of numerous vertically situated unresorbed hyperostoses inside. The osteoporosis was more pronounced as was trabecular roughening with marked horizontal stress lines. It was obvious that prednisone therapy the previous year had had no effect.

IV. 11. A male, born on 2 March 1969. Symptoms

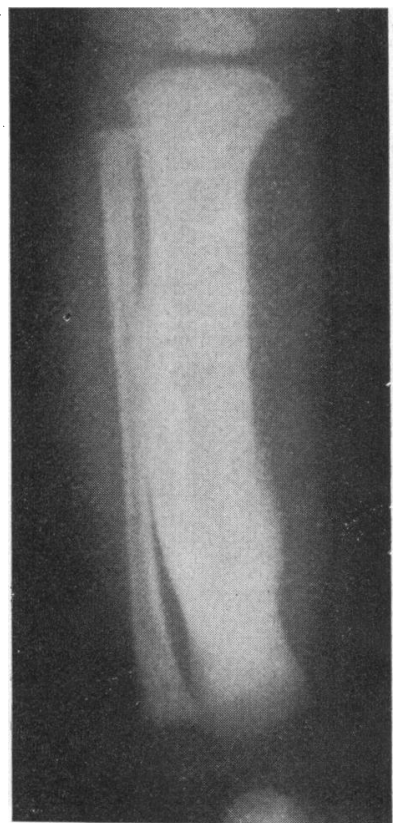

FIG. 2.-Propositus. Early stage of infantile cortical hyperostosis. Hyperostoses on left tibial diaphysis, marrow cavity not extended, long axis of the bone preserved, metaphyses and epiphyses not affected.

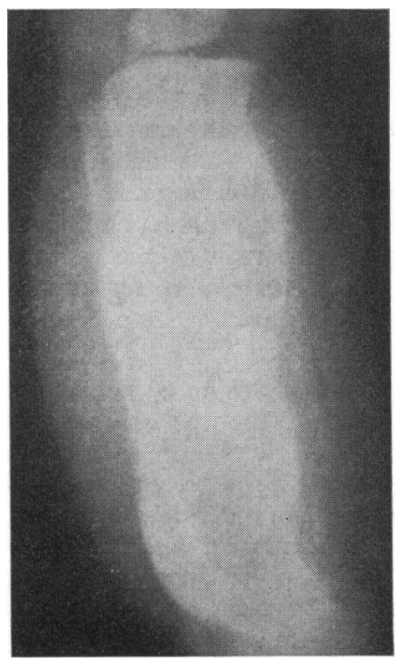

FIG. 3.-Propositus. X-ray of tibia and fibula at 12 months of age.

appeared 3 weeks later with painful swelling of the lower jaw. The left clavicle, both femora, and tibiae subsequently became affected during the early stages of the disease. At 2 years no physical signs were present, but 


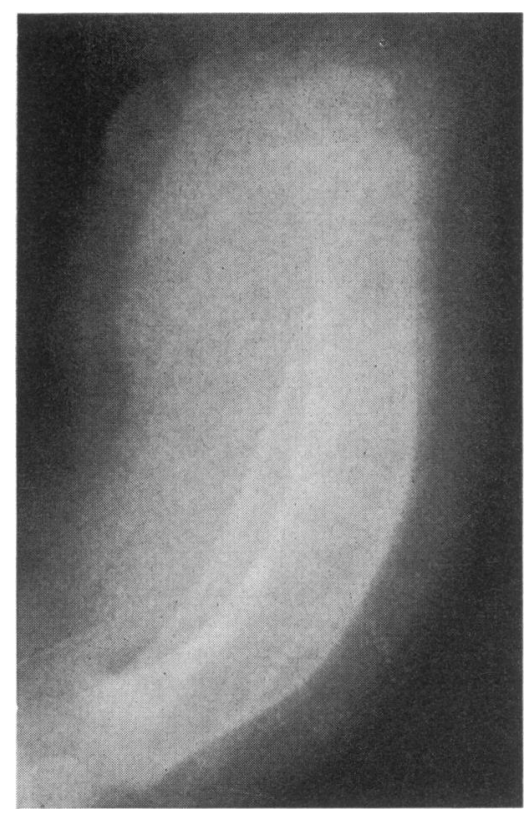

Fig. 4.-Propositus. X-ray of tibia and fibula at 2 years of age.

radiological signs were observed in both femora and tibiae. The femora were laterally bowed whereas the tibiae were curved forward. The corticalis was very thin with no appositions in the femora. Unresorbed hyperostoses were present in the tibiae. The marrows were enlarged with resorbing vertically orientated hyperostoses in the tibiae. Osteoporosis was present in the tibiae but not in the femora. At 4 years of age (Fig. 6) the bone curving was less marked. The corticalis had grown, the marrow decreased, osteoporosis was less marked, though there were remains of the original hyperostoses in the tibiae.

IV. 14. A female, born on 10 February 1968. Onset of symptoms was at 3 months with painful swelling of the left leg. Both clavicles, humeri, and tibiae were also affected. At 2 years no physical findings were present. Radiology showed lateral curving of both humeri with a thin corticalis and enlarged marrow, but no obvious osteoporosis. Both tibiae were curved in an anterofibular position with a thin corticalis, enlarged marrow with the remains of unresorbed hyperostoses inside, and osteoporosis.

At the age of 5 years radiology showed no more abnormalities of the humeri, though slight anterofibular deviation of the tibiae (Fig. 7) remained with a slightly thinner corticalis. The marrow was still slightly enlarged with the remains of unresorbed hyperostoses. Mild osteoporosis and mild roughening of the trabeculae of the spongiosis were also still observed.

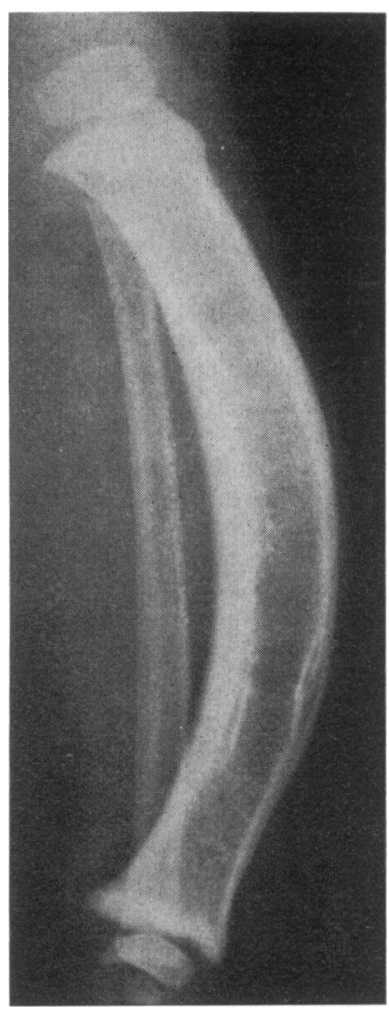

FIG. 5.-Propositus. X-ray of tibia and fibula at 3 years of age.

\section{Discussion}

This report indicates that some cases of infantile cortical hyperostosis can be familial. The two, and possibly three, generations studied imply that both sexes are affected equally and that the mechanism of heredity is an autosomal dominant one with an approximate $50 \%$ risk of recurrence to offspring of an affected individual married to a healthy partner. Consequently the genetic prognosis (in the sense of recurrence risk) is unfavourable, but this is fully balanced by the benign character of the condition, the clinical and radiological signs of which have usually disappeared completely by the second year of life. Persistence of symptoms after this age is unusual but should be considered for reasons of differential diagnosis.

It seems that the more chronic form of the disease, as observed in our 3 cases, is characterized in its later phases only by typical radiological findings, mostly in the long bones which may be curved; this disappears eventually in some cases but may be permanent in others. The initially thin corticalis 


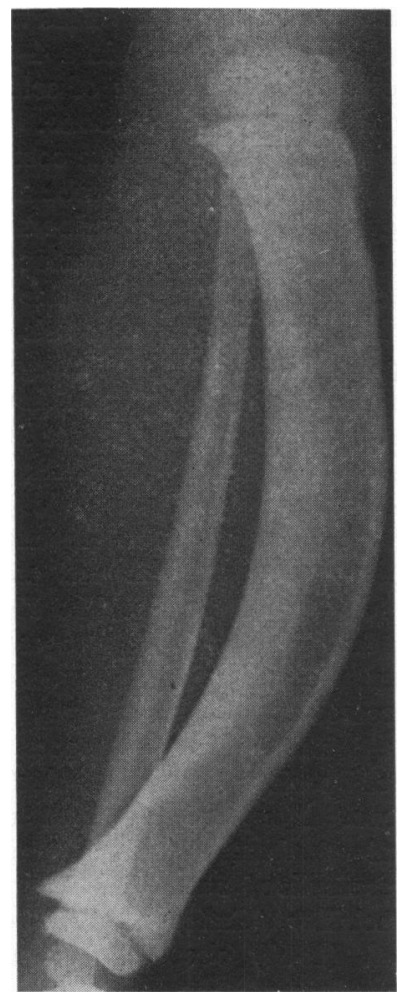

Fig. 6.-IV. II. X-ray of tibia and fibula at 4 years of age.

thickens and the enlarged marrow becomes narrower with persisting dense strips, varying in length, of vertically orientated unresorbed hyperostoses, observed most frequently in the tibiae. In protracted forms of infantile cortical hyperostosis, osteoporosis and roughening of the trabeculae in the spongiosis-mostly of the tibia-was found regularly. (More serious cases could be treated with vitamin $\mathrm{D}$, calcium, and anabolic steroids.) Neither the metaphyses nor epiphyseal ossification was affected by the process.

It is possible that the gene responsible for the condition varies in expressivity. Thus some cases are mild and may be missed without extensive radiological investigation, whereas others incline towards a more severe and prolonged course of the disease.

Genetics. The majority of cases reported are isolated ones, with both sexes affected equally. Barba and Freriks (1953), Sidbury and Sidbury (1954), and Snobl, Naugelborevova, and Tuma (1968) all reported families with 2 affected sibs in

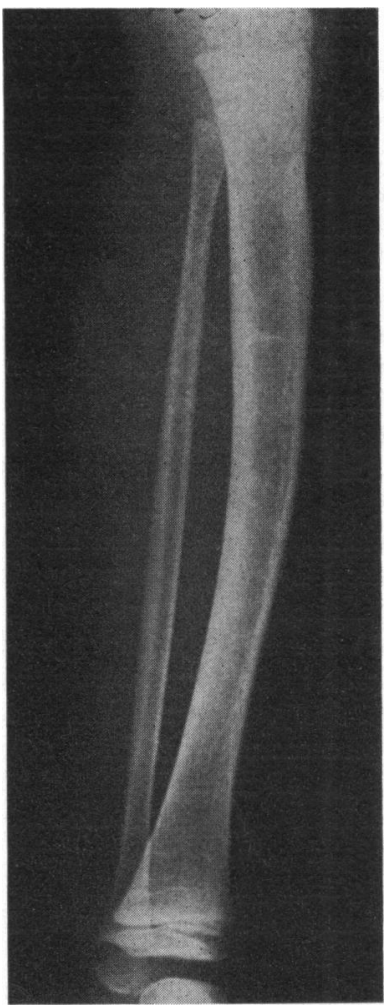

Fig. 7.-IV. 14. X-ray of tibia and fibula at 5 years of age.

each; Clemett and Williams (1963) reported 3 affected brothers. These cases all seem to be compatible with an autosomal recessive mechanism of heredity (though it is unclear to what extent the parents were investigated). In families with sporadic cases, spontaneous dominant mutation must also be considered.

A few reports have been published in which infantile cortical hyperostosis has been observed in more than one generation. Kitchin (1951) reported an affected mother and daughter; Veller and Laur (1953) an affected father and daughter; Zeben (1948) an affected brother, sister, and cousin; Pelikán, Doubravský, and Mikeš (1967) 2 affected cousins. Ševčík and Malý (1960) reported a mother, daughter, and 2 cousins, and extensive pedigrees were published by Gerrard et al. (1961) and by Van Buskirk et al. (1961). All these cases are compatible with an autosomal dominant type of heredity.

Review of cases with prolonged course beyond the second year of life. 
I. Acute phase of infantile cortical hyperostosis after second year of life. Caffey (1957) reported a patient with episodes of recurrent swelling of the lower jaw with persisting thickening and mandibular sclerosis, which he had observed from infancy until 7 years of age. Śevčík and Malý (1960) observed radiological hyperostoses at the tibial margin of the proximal metaphysis of the left fibula in a patient 20 years after an acute episode of infantile cortical hyperostosis had been suspected; however, the site of hyperostosis was atypical in this case. Altman and Pomerance's (1961) case was a 5-year-old girl in whom symptoms were initially observed to be reminiscent radiologically of infantile cortical hyperostosis and Engelmann-Camurati's disease. Neither was confirmed histologically and infantile cortical hyperostosis was unlikely because damage was limited to the periosteum.

Faul (1961) observed spindle appositions on the tibular corticalis in 2 brothers, aged 5 years and 39 years, respectively. Corda and Scano (1969) reported hyperostoses on the first metacarpal and on the phalanges of the left thumb in a 26-monthold child; this is an atypical site for infantile cortical hyperostosis, and the first observation of hyperostoses on the phalanges.

Two additional cases of late onset infantile cortical hyperostosis were reported by Swerdloff, Ozonoff, and Gyepes in 1970. One was a boy of $12 \frac{1}{2}$ years, in whom typical hyperostoses of the left tibia and femur were observed, together with raised alkaline phosphatase (other laboratory data were normal) and the other a girl aged 3 years 9 months who had pain and hyperostoses on the tibial margins of both tibial diaphyses which disappeared 12 months later, though a residual narrow zone of new bone formation at the fibular margin of the left tibia and in the extensor area of the left ulna was seen radiologically. Blank's (1975) case was a 12-year-old boy in whom occasional aches and new cortical thickenings in the arms and legs were repeatedly observed.

II. Chronic form of infantile cortical hyperostosis. Pajewski and Vure (1967) presented data obtained from 2 patients: a girl, 15 years of age, with changes on the right femur (bowing of the bone forward, thin corticalis, and extended marrow cavity); and a man, 31 years of age, with changes of both femora and tibiae (the femora were curved forward, with thin corticalis of femora and tibiae, extended marrow cavities containing residual unresorbed original hyperostoses).

III. Residual changes after infantile cortical hyperostosis, persisting beyond the second year of age.
(A) Mandibular asymmetry. This was observed by Caffey and Silverman (1945) in a 4-year-old boy with the positive $x$-ray findings of sclerosis of the mandible and left zygomatic bone. 11 patients with a previous history of infantile cortical hyperostosis were also investigated by Burbank, Lovestedt, and Kennedy (1958), who described mandibular asymmetry with subsequent malocclusion but no damage of dentition. Mandibular asymmetry, following infantile cortical hyperostosis, was further shown in 2 patients ( 8 and 9 years of age) by Staheli Church, and Ward (1968). Mandibular undergrowth with malocclusion following infantile cortical hyperostosis was described by Blank in a boy 3 years of age. Weis and Lewis (1969) concluded that there were no significant differences between the mandibles of a carefully investigated group of 8 boys and 10 girls, aged from 4 to 13 years, who had had infantile cortical hyperostosis and a control group.

(B) Interosseous bony bridges. Reciprocal pressure of neighbouring hyperostoses can lead to necrosis of the periosteum and to local fusion of the appositions. Bony bridges on the ribs (Caffey, 1952; Staheli et al., 1968) had no unfavourable effect on respiration, but those in the forearm restricted mobility (Caffey, 1952; Scott, 1963). Staheli et al. (1968) observed no unfavourable effect upon the lower limbs.

(C) Persisting bowing of the long bones. Barba and Freriks (1953) observed bowing of both tibiae in a boy $2 \frac{1}{2}$ years of age. Thickening of the tibial corticalis and bowing of the radius in a 19-year-old girl was shown by Idbohrn, Lindegard, and Lindquist (1956). Van Buskirk et al. (1961) reported curving of the femora and tibiae in a man 25 years of age. Slight deformity of both radii, and barely apparent sigmoid bowing of the long axis of both ulnae in a woman (age not given) was described by Sevčík and Malý (1960). Anterior bowing of the right tibia in a boy $4 \frac{1}{2}$ years of age was reported by Clemett and Williams (1963), while fibular bowing of the tibia in a child 9 years of age was observed by Staheli et al. (1968), and Corda and Scano (1969) found bowing of the left humerus and ulna in a girl 26 months of age.

\section{REFERENCES}

Altman, H. S., and Pomerance, H. H. (1961). Chronic polyostotic periostitis of unknown etiology. Pediatrics, 28, 719.

Barba, W. P., and Freriks, D. J. (1953). The familial occurrence of infantile cortical hyperostosis in utero. Fournal of Pediatrics, 42, 141.

Bennett, H. S., and Nelson, T. R. (1953). Prenatal cortical hyperostosis. British Fournal of Radiology, 26, 47.

Blank, E. (1975). Recurrent Caffey's cortical hyperostosis and persistent deformity. Pediatrics, 55, 856. 
Burbank, P. M., Lovestedt, S. A., and Kennedy, R. L. (1958), The dental aspects of infantile cortical hyperostosis. Oral Surgery, Oral Medicine and Oral Pathology, 11, 1126.

Caffey, J. (1939). Syphilis of skeleton in early infancy-nonspecificity of many of the roentgenographic changes. American fournal of Roentgenology, Radium Therapy and Nuclear Medicine, 42, 637.

Caffey, J. (1946). Infantile cortical hyperostoses. Fournal of Pediatrics, 29, 541.

Caffey, J. (1952). On some late skeletal changes in chronic infantile cortical hyperostoses. Radiology, 59, 651 .

Caffey, J. (1957). Infantile cortical hyperostosis: a review of the clinical and radiographic features. Proceedings of the Royal Society of Medicine, 50, 347

Caffey, J. and Silverman, W. A. (1945). Infantile cortical hyperostoses: preliminary report on a new syndrome. American fournal of Roentgenology, Radium Therapy and Nuclear Medicine, 54, 1

Chiari, O. (1938). Über periostale Reaktionen bei nicht Luetischen Kindern im ersten Trimenon. Acta Paediatrica Scandinavica, 2, 436.

Clemett, A. R., and Williams, J. H. (1963). The familial occurrence of infantile cortical hyperostosis. Radiology, 80, 409.

Corda, R., and Scano, V. (1969). Contributo alla conoscenza dell' iperostosi corticale infantile. Minerva Pediatrica, 20, 861. de Toni, G. (1943). Una nuova malattia dell'apparato osseo: la poliosteopatia deformante connatale regressiva. Policlinico Infantile, 11, 201.

Ellis, R. W. B. (1939). Vitamin-C deficiency and periostitis of both ulnae: ? scurvy. Proceedings of the Royal Society of Medicine, $32,139$.

Eversole, S. L., Holman, G. H., and Robinson, R. A. (1957). Hitherto undescribed characteristics of the pathology of infantile cortical hyperostosis (Caffey's disease). Bulletin of the fohns Hopkins Hospital, 101, 80.

Faul, R. (1961). Familiäres Auftreten der infantilen kortikalen Hyperostose. Archiv für Kinderheilkunde, 164, 271.

Gerrard, J. W., Holman, G. H., Gorman, A. A. and Morrow, I. H. (1961). Familial infantile cortical hyperostosis. Fournal of Pediatrics, 59, 543.

Idbohrn, H., Lindegard, B., and Lindquist, B. (1956). Caffey's syndrome: infantile cortical hyperstosis. Läkartidningen, 53, 3482.

Jenkinson, E. L., Pfisterer, W. H., Latteier, K. K. and Martin, M. (1943). A prenatal diagnosis of osteopetrosis. American fournal of Roentgenology, Radium Therapy and Nuclear Medicine, 49, 455.

Kitchin, I. D. (1951). An atypical case of infantile cortical hyperostosis. Fournal of Bone and foint Surgery, 33B, 248.

Klotz, M. (1939). On a strange case of hyperplastic periostitis of undertermined aetiology (fluorine poisoning?) in an infant. Archiv für Kinderheilkunde, 117, 267.

Meier, A. (1936). Periostitis hyperplastica bei einem 3 Monate alten Frühgeborenen. Archiv für Kinderheilkunde, 109, 223.
Mossberger, J. I. (1950). Infantile cortical hyperostosis: report of a case with observation at autopsy. American fournal of Diseases of Children, 80, 610.

Pajewski, M., and Vure, E. (1967). Late manifestations of infantile cortical hyperostosis. British fournal of Radiology, 40, 90.

Pelikán, L., Doubravský, J., and Mikeš, K. (1967). Familial occurrence of infantile cortical hyperostosis. Acta Chirurgiae Orthopaedicae et Traumatologiae Cechoslovaca, 34, 430.

Roske, U. (1930). Eine eigenartige Knochenerkrankung im Säuglingsalter. Monatsschrift für Kinderheilkunde, 47, 385.

Sauterel, L., and Rabinowicz, T. (1961). A new etiological aspect of infantile cortical hyperostosis. Annales de Radiologie, 4, 211.

Scott, E. P. (1963). Infantile cortical hyperostosis. Report of an unusual complication. Fournal of Pediatrics, 62, 782.

Sevčik, P., and Malý, V. (1960). Hyperostosis corticalis. Ceskoslovenská Rentgenologie, 14, 122.

Sidbury, J. B., Jr., and Sidbury, J. B. (1954). Infantile cortical hyperostosis: an inquiry into the etiology and pathogenesis. New England fournal of Medicine, 250, 309.

Smyth, F. S., Potter, A., and Silverman, W. A. (1946). Periosteal reaction, fever and irritability in young infants: a new syndrome? American fournal of Diseases of Children, 71, 333.

Snobl, O., Naugelborevova, L., and Tuma, S. (1968). A case of infantile cortical hyperostosis in two siblings. Ceskoslovenskd Radiologie, 22, 122.

Staheli, L. T., Church, C. C., and Ward, B. H. (1968). Infantile cortical hyperostosis (Caffey's disease): sixteen cases with a late follow-up of eight. Fournal of the American Medical Association, 302, 384

Swerdloff, B. A., Ozonoff, M. B., and Gyepes, M. T. (1970). Late recurrence of infantile cortical hyperostosis. American fournal of Roentgenology, Radium Therapy and Nuclear Medicine, 108, 461.

Van Buskirk, F. W., Tampas, J. P., and Peterson, O. S., Jr. (1961), Infantile cortical hyperostosis: an inquiry into its familial aspects. American fournal of Roentgenology, Radium Therapy and Nuclear Medicine, 85, 613.

Veller, K., and Laur, A. (1953). Zur Åtiologie der infäntilen kortikalen Hyperostose. Fortschritte auf dem Gebiete der Röntgenstrahlen vereinigt mit Röntgenprascis, 79, 446.

Weis, R. W., and Lewis, T. M. (1969). Infantile cortical hyperostosis: a study to determine if residual deformities exist in mandibles. Fournal of Dentistry for Children, 36, 441.

West, S. (1888). Acute periosteal swellings in several young infants of the same family, probably rickety in nature. British Medical fournal, 1, 856.

Zeben, W. Van (1948). Infantile cortical hyperostosis. Acta Paediatrica, 35, 10.

Correspondence to Dr. L. Fráňa, Department of Paediatrics, Hospital, 59231 Nové Město na Moravě, Czechoslovakia. 